\title{
The Influence of Lithium and/or Selenium Treatment on Homeostasis of Chosen Bioelements in Rats
}

\author{
Malgorzata Kiełczykowska $^{1}$ - Irena Musik ${ }^{1}$. Jacek Kurzepa ${ }^{1} \cdot$ Renata Żelazowska $^{1}$. \\ Anna Lewandowska ${ }^{1}$ • Marek Paździor ${ }^{2}$ • Joanna Kocot ${ }^{1}$
}

Received: 12 September 2016/Accepted: 28 November 2016/Published online: 12 December 2016

(C) The Author(s) 2016. This article is published with open access at Springerlink.com

\begin{abstract}
Lithium is widely used in medicine and the therapy is often long term. Apart from beneficial effects, its application can cause diverse side effects. The current study was performed with the aim of the evaluation of the effect of lithium and/or selenium administration on magnesium, calcium and silicon levels in rats. The study was performed on rats divided into four groups (six animals each): control—received saline, $\mathrm{Li}$-received $\mathrm{Li}_{2} \mathrm{CO}_{3}(2.7 \mathrm{mg} \mathrm{Li} / \mathrm{kg}$ b.w.), $\mathrm{Se}$-received $\mathrm{Na}_{2} \mathrm{SeO}_{3} \cdot \mathrm{H}_{2} \mathrm{O}(0.5 \mathrm{mg} \mathrm{Se} / \mathrm{kg}$ b.w.), and $\mathrm{Li}+\mathrm{Se}-\mathrm{re}-$ ceived simultaneously $\mathrm{Li}_{2} \mathrm{CO}_{3}$ and $\mathrm{Na}_{2} \mathrm{SeO}_{3} \cdot \mathrm{H}_{2} \mathrm{O}(2.7$ and $0.5 \mathrm{mg} \mathrm{Se} / \mathrm{kg}$ b.w.). The administration was performed in form of water solutions by a stomach tube once a day for 6 weeks. In the organs (liver, kidney, brain, spleen, heart, lung and femoral muscle), the concentrations of magnesium, calcium and silicon were determined. Lithium significantly increased $\mathrm{Ca}$ in the kidney, brain and spleen. Coadministration of selenium reversed this effect. No changes of magnesium in organs were observed. Silicon was affected only in spleen - an increase vs. control was observed in all studied groups. The beneficial influence of coadministration of selenium in case of calcium lets us suggest that an issue of its possible use as an adjuvant alleviating side effects in lithium-treated subjects is worth being continued.
\end{abstract}

Keywords Lithium · Selenium · Magnesium · Calcium · Silicon $\cdot$ Male rats

Joanna Kocot

joanna.kocot@umlub.pl

1 Chair and Department of Medical Chemistry, Medical University of Lublin, Chodźki 4a, 20-093 Lublin, Poland

2 Traumatic-Orthopaedic and Spine Surgery Ward of Independent Public Health Care Centre in Puławy, Józefa Bema 1, 24-100 Puławy, Poland

\section{Introduction}

For many years, lithium carbonate has been used in medicine, mostly in psychiatry $[1,2]$. However, studies have revealed the possibility of its application in other fields, e.g. in cure of thyroid and neurodegenerative disturbances [2-4]. Lithium chloride application in turn has been suggested to be effective in leukaemia therapy [5]. Apart from a beneficial influence, lithium therapy can be accompanied with diverse side effects including parathyroid, renal and thyroid disorders [6, 7]. The additional impediment for the clinicians is the fact that lithium is characterized by a narrow therapeutic range which must not be exceeded [8]. However, in cases of bipolar disorder, lithium therapy remains a first choice maintenance treatment [9].

The research on an adjuvant which could alleviate lithium's side effects seems to be worth performing, all the more that the therapy is often long term. Moreover, the possibility of growing environmental pollution with lithium, resulting from its growing use, has been reported [10]. Harrari et al. have reported that the lithium occurrence in drinking water should also be considered as a potential threat for consumers [11]. Having regarded that diverse bioelements proved to protect against different harmful factors, including chemical substances of toxic properties, we chose selenium to be studied in regard to its possible beneficial influence on organisms subjected to lithium. Selenium has already been found to show protective action against both physical and chemical factors, as well as against side effects of drugs [12-14]. Additionally, an organic compound ebselen containing selenium has been proved to possess some lithium-mimetic properties [15]. As to the used form of selenium, for this pilotage study, an inorganic 
sodium selenite has been chosen, considering its bioavailability and continuous application in animal studies as well as in clinical practice $[16,17]$.

Lithium has already been reported to show relationships with homeostasis of different bioelements, both macro- and microelements [11, 18, 19]. Lithium and magnesium ions have been reported to compete for binding site of some enzymes [20]. Neuroprotective action of lithium has been suggested to be linked with the influence on intracellular concentrations of calcium ions [3]. Hypercalcaemia may occur in lithium-received subjects and despite investigations, the mechanism of this effect has not been fully clarified yet $[6,21]$. Silicon, an essential microelement has been found to be influenced by lithium administration [19].

The current study was performed with the aim of evaluating the effect of lithium administration on chosen bioelements-magnesium, calcium and silicon-in rats as well as the possibility of selenium application as an adjuvant in lithium therapy.

\section{Materials and Methods}

\section{Experimental Animals}

The experiment was carried on adolescent male Wistar rats (24 animals, $130-160 \mathrm{~g}$ body weight). The animals had free access to standard feed (LSM produced by AGROPOL S.J., Motycz, Poland, without lithium and selenium supplementation) and drinking water. The composition of the diet is presented in Table 1.

The study was performed according to statutory bioethical standards and approved by I Local Ethical

Table 1 Composition of standard LSM feed

\begin{tabular}{lll}
\hline Substance & Unit & Content \\
\hline Protein min. & {$[\%]$} & 16.00 \\
Raw fats min. & {$[\%]$} & 2.80 \\
Raw ash max. & {$[\%]$} & 7.00 \\
Raw fibre max. & {$[\%]$} & 5.00 \\
L-Lysine min. & {$[\%]$} & 0.80 \\
DL-Methionine min. & {$[\%]$} & 0.50 \\
Calcium min. & {$[\%]$} & 1.10 \\
Phosphorus min. & {$[\%]$} & 0.60 \\
Sodium max. & {$[\%]$} & 0.20 \\
Vitamin A (retinol) E 672 & {$[\mathrm{jm} / \mathrm{kg}]$} & 10,000 \\
Vitamin D3 E 671 & {$[\mathrm{jm} / \mathrm{kg}]$} & 1500 \\
Vitamin E ( $\alpha$-tocopherol 50\%) & {$[\mathrm{mg} / \mathrm{kg}]$} & 25 \\
Copper (copper sulphate 24.5\%) E 4 & {$[\mathrm{mg} / \mathrm{kg}]$} & 5 \\
\hline
\end{tabular}

Commission of Medical University of Lublin, acceptance no.1/2013.

\section{Experimental Design}

After an acclimatization period of 3 days, the animals were divided randomly into four groups (six animals each). The treatments were as follows:

- control group - treated with saline,

- $\mathrm{Li}$ group - treated with lithium (as $\mathrm{Li}_{2} \mathrm{CO}_{3}$ ) at a dose of $2.7 \mathrm{mg} \mathrm{Li} / \mathrm{kg}$ b.w.,

- Se group - treated with selenium $\left(\right.$ as $\left.\mathrm{Na}_{2} \mathrm{SeO}_{3} \cdot \mathrm{H}_{2} \mathrm{O}\right)$ at a dose of $0.5 \mathrm{mg} \mathrm{Se} / \mathrm{kg}$ b.w.,

- $\mathrm{Li}+\mathrm{Se}$ group - treated simultaneously with lithium $\left(\mathrm{Li}_{2} \mathrm{CO}_{3}\right)$ and selenium $\left(\mathrm{Na}_{2} \mathrm{SeO}_{3} \cdot \mathrm{H}_{2} \mathrm{O}\right)$ at a dose of $2.7 \mathrm{mg} \mathrm{Li} / \mathrm{kg} \mathrm{b.w.} \mathrm{and} \mathrm{of} 0.5 \mathrm{mg} \mathrm{Se} / \mathrm{kg}$ b.w., respectively.

The administration was performed in form of water solutions by a stomach tube, once a day, for a period of 6 weeks. Basing on the body mass of each animal, measured every day before administration, the appropriate amount of selenium and/or lithium solutions was calculated. Then the animals were sacrificed under thiopental narcosis and samples of the liver, kidney, brain, spleen, heart, femoral muscle and lung were collected. The organs were weighed when collected. Ten per cent $(w / v)$ tissue homogenates were prepared in $0.1 \mathrm{~mol} \mathrm{dm}{ }^{-3}$ Tris- $\mathrm{HCl}$ buffer, $\mathrm{pH}=$ 7.4. Supernatants were obtained by centrifugation at $5000 \times \mathrm{g}$ for $30 \mathrm{~min}$.

\section{Tissue Bioelement Analysis}

In the prepared tissue supernatants, the concentrations of magnesium, calcium and silicon were determined. Magnesium and calcium concentrations were assayed by colorimetric methods using diagnostic kits Liquick CorMG 60 and Liquick Cor-CALCIUM 120, respectively.

The concentration of silicon was measured using the spectrophotometric method described by Wielkoszyński [22]. Tissue homogenates were mixed with $10 \%$ trichloroacetic acid (TCA) solution in a volume ratio 1:1.6 and left for $30 \mathrm{~min}$ with the aim of deproteination. Then the samples were centrifuged $(13,000 \times \mathrm{g}, 10 \mathrm{~min})$ and $0.5 \mathrm{~cm}^{3}$ of supernatant was collected. Then $1 \mathrm{~cm}^{3}$ of $0.5 \%$ solution of ammonium molybdate $\left(\mathrm{NH}_{4}\right)_{6} \mathrm{Mo}_{7} \mathrm{O}_{24} \cdot 4 \mathrm{H}_{2} \mathrm{O}$ in $30 \%$ acetic acid was added and the samples were kept in water bath $\left(80{ }^{\circ} \mathrm{C}\right.$ ) for $5 \mathrm{~min}$. After cooling, $0.5 \mathrm{~cm}^{3}$ of $4 \%$ sodium potassium tartrate solution in $4 \mathrm{M} \mathrm{H}_{2} \mathrm{SO}_{4}$ and, after subsequent $2 \mathrm{~min}, 1 \mathrm{~cm}^{3}$ of $2 \%$ water solution of ascorbic acid were added. After the next $5 \mathrm{~min}$, the absorption of the obtained samples was read at wavelength $800 \mathrm{~nm}$ 
against the blank prepared as described above with using distilled water instead of tissue homogenates. Silicon concentration was measured basing on the standard curve prepared with using silicon standard Titrisol-Silicium (Merck).

The obtained values of the determined elements' concentrations were expressed in micromoles per gram of wet tissue. The assays were performed using spectrophotometer SPECORD M40 (Zeiss Jena).

\section{Statistical Analysis}

All statistical analyses were performed using the STATISTICA program (version 10.0). The normality of data distribution was verified using the Shapiro-Wilk test. The differences among the studied groups were analysed using a one-way analysis of variance (ANOVA), followed by the Tukey test (for normally distributed variables) or Kruskal-Wallis one-way analysis of variance (for nonnormally distributed variables). Values were considered significant with $p<0.05$.

\section{Results}

\section{Body Weight Gain, Feed and Water Intake and Organ Weights of the Experimental Animals}

The experimental animals' body weight enhanced during all experiments showing no statistical differences among the groups. However, the slight increase in Li-treated rats as well as a little depletion in Se-given rats vs. control was observed (see Fig. 1).
The values of intake of feed and water showed no differences among the control and the studied groups of rats $(\mathrm{Li}$ treated, Se treated and $\mathrm{Li}+\mathrm{Se}$ treated) during all the experiments.

Generally, the weight of the studied organs did not show significant differences among the studied groups, except for liver and kidney, where a significant decrease in Li-treated animals vs. control was observed. Additionally, liver weights in Se-alone and $\mathrm{Li}+\mathrm{Se}$-treated groups were significantly enhanced compared to the Lialone group (see Table 2).

\section{Calcium Level in Organs of Rats}

Calcium level in the studied organs was considerably influenced. In the liver, it was decreased slightly by $\mathrm{Li}$ alone and significantly by Se alone compared to control. Coadministration of these both elements did not change liver $\mathrm{Ca}$ vs. control but a significant increase vs. Se alone was observed. In the kidney, lithium markedly increased $\mathrm{Ca}$ vs. control. Se, both alone and given with $\mathrm{Li}$, did not alter $\mathrm{Ca}$ vs. control but caused a significant decrease compared to the $\mathrm{Li}$ group. In the brain, $\mathrm{Li}$ alone resulted in a well-marked enhancement of $\mathrm{Ca}$ vs. control. The similar significant $\mathrm{Ca}$ enhancement vs. control was observed in the spleen, but in this organ, $\mathrm{Se}$ and $\mathrm{Li}+\mathrm{Se}$ treatment caused a well-marked depletion compared to the $\mathrm{Li}$ group. In the heart, $\mathrm{Li}$ alone caused an insignificant $\mathrm{Ca}$ decrease vs. control. Se, both alone and given with $\mathrm{Li}$, significantly increased $\mathrm{Ca}$ compared to $\mathrm{Li}$ group. In the lung, a slight $\mathrm{Li}$ increase vs. control was observed, whereas in the Li+Se group, a depletion vs. the Li group was noted. In femoral muscle, selenium
Fig. 1 Body weight gain of experimental animals

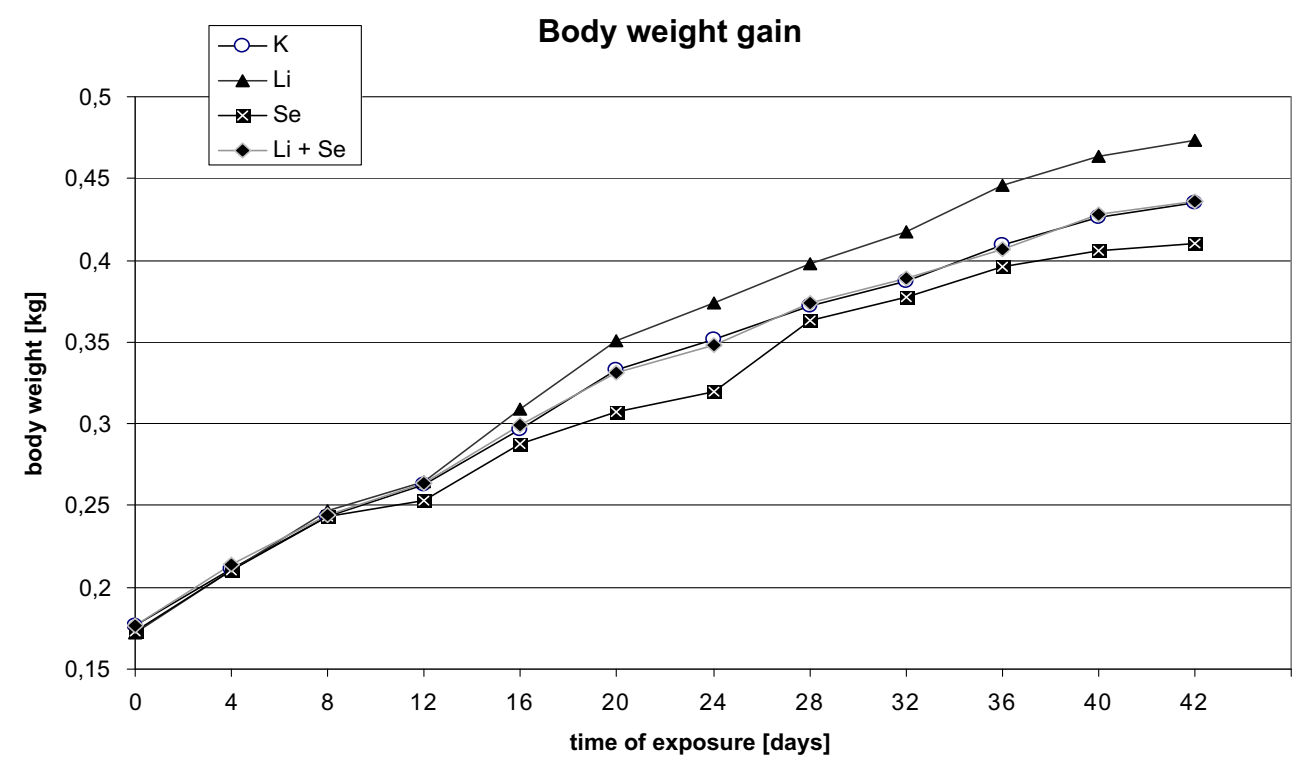


Table 2 Organ weight $[\mathrm{g}]$ of rats receiving lithium and/or selenium

\begin{tabular}{lllllll}
\hline Group & Liver & Kidney & Brain & Spleen & Heart & Lung \\
\hline $\mathrm{C}(n=6)$ & $7.9 \pm 0.7$ & $2.1 \pm 0.2$ & $1.3 \pm 0.3$ & $0.6 \pm 0.2$ & $0.7 \pm 0.2$ & $1.7 \pm 0.1$ \\
$\mathrm{Li}(n=6)$ & $5.5 \pm 0.4^{* *}$ & $1.4 \pm 0.4^{*}$ & $1.0 \pm 0.3$ & $0.8 \pm 0.3$ & $0.6 \pm 0.3$ & $1.6 \pm 0.1$ \\
$\mathrm{Se}(n=6)$ & $7.4 \pm 0.8^{\#}$ & $2.0 \pm 0.3$ & $1.2 \pm 0.8$ & $0.6 \pm 0.2$ & $0.6 \pm 0.3$ & $1.8 \pm 0.2$ \\
$\mathrm{Li}+\mathrm{Se}(n=6)$ & $7.3 \pm 0.6^{\#}$ & $1.9 \pm 0.3$ & $1.2 \pm 0.7$ & $0.6 \pm 0.2$ & $0.7 \pm 0.4$ & $1.7 \pm 0.3$ \\
\hline
\end{tabular}

Values are mean $\pm \mathrm{SD}$

${ }^{*} p<0.05$ vs. control; ${ }^{*} p p<0.01$ vs. control; ${ }^{\# \#} p<0.01$ vs. Li group significantly increased Ca vs. all the other groups. All the presented results are shown below (see Table 3).

\section{Magnesium Level in Organs of Rats}

In all the studied organs, magnesium was not disturbed significantly by any used treatment (see Table 4).

\section{Silicon Level in Organs of Rats}

Silicon level was markedly affected only in spleen where all the treatments significantly increased its level vs. control. Additionally, in the Se-alone group, Si was enhanced compared to the Li group. In the other organs, no significant differences among the studied groups were observed. The results are shown below (see Table 5).

\section{Discussion}

Lithium treatment applied in the current study, although rather short compared to therapy used in humans, resulted in a slight increase in body weight vs. control. It is consistent with the findings revealing the occurrence of body weight gain in patients undergoing lithium therapy [7].

In the previous part of our research, we found that lithium treatment significantly decreased serum $\mathrm{Mg}$ and enhanced serum $\mathrm{Ca}$ [23]. In contrast, in the current study, magnesium in organs was not affected by Li treatment, whereas calcium was changed in the studied organs in different ways. These results suggest that alterations observed in serum do not fully reflect changes of these elements' homeostasis in all organisms. Such observations seem to be important and point to the usefulness of the animal model studies, as lithium therapy is applied in humans and the only possible monitoring of its effect is the determination of blood parameters. Moreover, the results concerning lithium's influence on blood calcium are not consistent. Although hypercalcaemia is included into side effects of Li therapy, Zamani et al. did not observe any difference in corrected total calcium between patients receiving maintenance lithium therapy and healthy control [1]. Harrari et al. reported a depletion of urinary calcium across the tertiles of lithium concentration in the blood of pregnant women, inhabitants of an area with Li-containing drinking water. However, no changes of total serum calcium were observed. The authors suggested that the disturbances of calcium homeostasis were connected with vitamin D [11] what is consistent taking into account that kidney disorders are one of the main negative effects of lithium administration [24]. Other studies also revealed the occurrence of vitamin D disturbances in subjects treated with lithium [25].

In the current study, calcium was the most affected bioelement in organs by lithium and the prevailing effect was an increase vs. control. The relationships between the homeostasis of this element and lithium have already been reported, and the results were not consistent as well as showed time dependence. Baltaci et al. observed a significant increase in bone $\mathrm{Li}$ in ovariectomized rats fed zinc-deficient diet, and this effect was accompanied with a well-marked depletion of bone calcium [26]. Tkatcheva et al. found a time dependence of lithium's influence on calcium in fish brain. While at the beginning, Ca remained unaltered; after $24 \mathrm{~h}$, a slight decrease

Table 3 Calcium concentrations $\left[\mu \mathrm{mol} \mathrm{g}{ }^{-1}\right.$ of wet tissue] in organs of rats receiving lithium and/or selenium

\begin{tabular}{|c|c|c|c|c|c|c|c|}
\hline Group & Liver & Kidney & Brain & Spleen & Heart & Lung & Femoral muscle \\
\hline Control $(n=6)$ & $3.6 \pm 0.6$ & $6.9 \pm 1.3$ & $3.0 \pm 0.7$ & $7.8 \pm 1.6$ & $8.1 \pm 2.9$ & $9.0 \pm 2.5$ & $2.6 \pm 0.6$ \\
\hline $\operatorname{Li}(n=6)$ & $2.8 \pm 0.8$ & $10.6 \pm 1.1 * * *$ & $5.3 \pm 2.4^{*}$ & $12.1 \pm 1.7 * * *$ & $5.2 \pm 1.9$ & $10.7 \pm 1.4$ & $3.9 \pm 1.0$ \\
\hline $\mathrm{Se}(n=6)$ & $1.8 \pm 0.5^{*}$ & $6.4 \pm 1.2^{\# \# \#}$ & $3.0 \pm 0.6$ & $7.9 \pm 0.4^{\# \# \#}$ & $10.9 \pm 1.8^{\# \#}$ & $8.0 \pm 1.8$ & $7.7 \pm 1.6^{* * *}$, \\
\hline $\mathrm{Li}+\mathrm{Se}(n=6)$ & 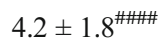 & $5.1 \pm 1.0^{\# \# \#}$ & $4.9 \pm 0.6$ & $8.0 \pm 0.8^{\# \# \#}$ & $10.0 \pm 1.9^{\# \#}$ & $7.6 \pm 1.7^{\#}$ & 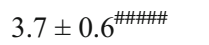 \\
\hline
\end{tabular}

Values are mean \pm SD

${ }^{*} p<0.05$ vs. control; *** $p<0.001$ vs. control; ${ }^{\#} p<0.05$ vs. Li group; ${ }^{\#} p<0.01$ vs. Li group; ${ }^{\# \#} p<0.001$ vs. Li group; ${ }^{\# \# \# ~} p<0.05$ vs. Se group; \#\#\#\# $p<0.001$ vs. Se group 
Table 4 Magnesium concentrations $\left[\mu \mathrm{mol} \mathrm{g}{ }^{-1}\right.$ of wet tissue] in organs of rats receiving lithium and/or selenium

\begin{tabular}{llllllll}
\hline Group & Liver & Kidney & Brain & Spleen & Heart & Lung & Femoral muscle \\
\hline $\mathrm{C}(n=6)$ & $7.6 \pm 1.0$ & $7.0 \pm 1.1$ & $3.4 \pm 0.4$ & $8.3 \pm 0.4$ & $7.9 \pm 0.6$ & $4.8 \pm 0.5$ & $11.1 \pm 0.7$ \\
$\mathrm{Li}(n=6)$ & $7.6 \pm 0.5$ & $7.8 \pm 0.7$ & $3.6 \pm 0.7$ & $8.6 \pm 0.7$ & $8.0 \pm 0.6$ & $5.0 \pm 0.3$ & $11.2 \pm 2.4$ \\
$\mathrm{Se}(n=6)$ & $7.6 \pm 0.9$ & $6.9 \pm 0.5$ & $3.6 \pm 0.2$ & $7.5 \pm 0.6$ & $8.2 \pm 0.3$ & $4.7 \pm 1.6$ & $12.1 \pm 0.7$ \\
$\mathrm{Li}+\mathrm{Se}(n=6)$ & $8.2 \pm 0.6$ & $7.4 \pm 0.5$ & $3.5 \pm 0.4$ & $8.0 \pm 0.2$ & $8.2 \pm 1.0$ & $4.4 \pm 0.4$ & $11.3 \pm 0.7$ \\
\hline
\end{tabular}

Values are mean $\pm \mathrm{SD}$ compared to control was obtained. The lengthening of intoxication up to $72 \mathrm{~h}$ resulted in a slight increase but after $96 \mathrm{~h}$, no changes were observed again [10]. Another study revealed a dentin Ca decrease in a patient undergoing Li therapy [27].

Irrespective of the studied organ, in the present experiment, no used treatment affected the magnesium tissue level. The lack of brain $\mathrm{Mg}$ changes seems to be vital since magnesium is considered to be one of the most important elements for the central nervous system [28]. Our results are supported by the outcomes reported by other researchers. According to Sivrikaya, intraperitoneal sodium selenite did not influence $\mathrm{Mg}$ in rat liver [29]. One of our previous experiments revealed no effect or increase in tissue $\mathrm{Mg}$ in rats receiving the similar Li doses in drinking water [30]. $\mathrm{LiCl}$ provided with drinking water did not alter magnesium in chosen organs (brain, liver, skeletal muscle and cardiac muscle) of rats [31]. A study carried out on ovariectomized rats fed Zn-deficient diet showed that while bone Li was increased, no alterations of bone magnesium were observed [26]. However, other scientists reported the time-dependent lithium's effect on brain magnesium in fish. During the first $48 \mathrm{~h}$ of the experiment, no alterations were observed, but after 72 and $96 \mathrm{~h}$, a slight decrease vs. control was obtained [10]. No influence of any treatment used in our experiment on the liver $\mathrm{Mg}$ is also very substantial as the proper functioning of this detoxifying organ is an issue of great importance, particularly that psychiatric subjects must undergo a long-term therapy [2] and some connections among magnesium, selenium and disturbances of the liver have already been reported $[32,33]$.

The human studies revealed little relationships between $\mathrm{Ca}$, $\mathrm{Mg}$ and selenium in organism. Özkaya et al. found that in women undergoing in vitro fertilization and receiving a multivitamin/mineral supplementation (containing $100 \mathrm{mg}$ of $\mathrm{Mg}$ and $125 \mathrm{mg}$ of Ca per 45 days), a considerable selenium increase in follicular fluid was accompanied with no effect on magnesium and calcium [34]. Crujeiras et al. found no changes of blood calcium in patients with hyperphenylalaninemia, although $25 \%$ of them showed depressed selenium [35]. In a human study concerning the relationships between these two elements, no effect of calcium supplementation on selenium parameters in adolescent girls was observed [36]. It can be another confirmation of usefulness of animal model.

The current study revealed that the administration of lithium and/or selenium did not affect silicon in any organ except for the spleen. The lack of any effect in the case of the brain seems to be worth underlying as lithium is used in psychiatric and neurological patients and silicon is considered to be essential for brain functions [37]. Generally, little information concerning relationships among these three bioelements can be found in the available literature data. In our department, the influence of lithium provided in drinking water on silicon in chosen rat organs was studied, revealing that comparable $\mathrm{Li}$ doses resulted mostly in no effect. A slightly higher dose enhanced $\mathrm{Si}$ in the liver and femoral muscle, whereas a lower one depleted the kidney Si level. But, first of all, a wide range of Li doses, applied in the mentioned study, did not change silicon in the brain [19]. As to the connections between selenium and silicon, this issue has been poorly investigated by to date. However, a silicon influx transporter OsNIP2;1 was suggested to be the first transporter of inorganic selenium (selenite form) in different organisms - plants, microorganisms and animals [38].

As side effects of lithium may considerably influence life condition of patients as well as their compliance, the research
Table 5 Silicon concentrations $\left[\mu \mathrm{mol} \mathrm{g}{ }^{-1}\right.$ of wet tissue] in organs of rats receiving lithium and/or selenium

\begin{tabular}{llllllll}
\hline Group & Liver & Kidney & Brain & Spleen & Heart & Lung & $\begin{array}{l}\text { Femoral } \\
\text { muscle }\end{array}$ \\
\hline $\mathrm{C}(n=6)$ & $3.4 \pm 1.2$ & $5.1 \pm 0.8$ & $0.9 \pm 0.3$ & $1.7 \pm 0.3$ & $0.5 \pm 0.1$ & $1.0 \pm 0.2$ & $1.6 \pm 0.3$ \\
$\mathrm{Li}(n=6)$ & $2.8 \pm 0.5$ & $3.7 \pm 0.9$ & $0.7 \pm 0.1$ & $2.4 \pm 0.4^{*}$ & $0.7 \pm 0.3$ & $1.1 \pm 0.4$ & $1.1 \pm 0.4$ \\
$\mathrm{Se}(n=6)$ & $3.5 \pm 0.8$ & $5.1 \pm 1.2$ & $1.1 \pm 0.5$ & $\begin{array}{c}3.2 \pm 0.2^{* * *} \\
\#\end{array}$ & $0.5 \pm 0.1$ & $0.8 \pm 0.4$ & $1.2 \pm 0.4$ \\
$\mathrm{Li}+\mathrm{Se}$ & $3.3 \pm 0.8$ & $4.5 \pm 1.1$ & $0.9 \pm 0.3$ & $2.5 \pm 0.6^{*}$ & $0.6 \pm 0.2$ & $1.1 \pm 0.3$ & $1.3 \pm 0.4$ \\
$\quad(n=6)$ & & & & & & & \\
\hline
\end{tabular}

Values are mean $\pm \mathrm{SD}$

$* p<0.05$ vs. control; $* * * p<0.001$ vs. control; ${ }^{*} p<0.05$ vs. Li group 
on agents alleviating lithium's negative influence has already been performed. Zinc was shown to be effective in improving of the disturbances of oxidant parameters, resulted from lithium exposure, in erythrocytes [39] and partially in the liver [40]. Some substances of natural origin, possessing the antioxidant properties, showed the similar protective influence in the kidney [41] and liver [42].

In the current experiment, the lithium-induced changes of studied parameters were reversed by coadministration of selenium, except for silicon in the spleen. These results let us suggest that selenium could be taking into account as an adjunct to lithium therapy, and farther studies of this issue seem to be worth undertaking.

Compliance with Ethical Standards The study was performed according to statutory bioethical standards and approved by I Local Ethical Commission of Medical University of Lublin, acceptance no.1/ 2013.

Funding This study was funded by the Medical University of Lublin.

Conflict of Interest The authors declare that they have no conflict of interest.

Open Access This article is distributed under the terms of the Creative Commons Attribution 4.0 International License (http:// creativecommons.org/licenses/by/4.0/), which permits unrestricted use, distribution, and reproduction in any medium, provided you give appropriate credit to the original author(s) and the source, provide a link to the Creative Commons license, and indicate if changes were made.

\section{References}

1. Zamani A, Omrani GR, Nasab MM (2009) Lithium's effect on bone mineral density. Bone 44:331-433. doi:10.1016/j.bone.2008.10.001

2. Ferensztajn-Rochowiak E, Rybakowski JK (2016) The effect of lithium on hematopoietic, mesenchymal and neural stem cells. Pharmacol Rep 68:224-230. doi:10.1016/j.pharep.2015.09.005

3. Wallace J (2014) Calcium dysregulation, and lithium treatment to forestall Alzheimer's disease - a merging of hypotheses. Cell Calcium 55:175-181. doi:10.1016/j.ceca.2014.02.005

4. Zheng R, Liu K, Chen K, Cao W, Cao L, Zhang H, Sun H, Liu C (2015) Lithium carbonate in the treatment of Graves' disease with ATD-induced hepatic injury or leukopenia. Int J Endocrinol 2015: 694023. doi: $10.1155 / 2015 / 694023$

5. Li L, Song H, Zhong L, Yang R, Yang XQ, Jiang KL, Liu BZ (2015) Lithium chloride promotes apoptosis in human leukemia NB4 cells by inhibiting glycogen synthase kinase-3 beta. Int J Med Sci 12:805-810. doi:10.7150/ijms. 12429 eCollection 2015

6. Shine B, McKnight RF, Leaver L, Geddes JR (2015) Long-term effects of lithium on renal, thyroid, and parathyroid function: a retrospective analysis of laboratory data. Lancet 386:461-468. doi:10.1016/S0140-6736(14)61842-0

7. Hayes JF, Marston L, Walters K, Geddes JR, King M, Osborn DP (2016) Adverse renal, endocrine, hepatic, and metabolic events during maintenance mood stabilizer treatment for bipolar disorder: a population-based cohort study. PLoS Med 13:e1002058. doi:10.1371/journal.pmed.1002058
8. de Oliveira TC, de Campos Neto IA, de Aguiar-Oliveira MH, de Pereira FA (2014) Evaluation of parathyroid function and mineral metabolism in psychiatric patients using lithium salts. Arq Bras Endocrinol Metabol 58:619-624. doi:10.1590/00042730000002983

9. Rybakowski JK (2016) Effect of lithium on neurocognitive functioning. Curr Alzheimer Res 13:887-893. doi:10.2174 $/ 1567205013666160415154701$

10. Tkatcheva V, Poirier D, Chong-Kit R, Furdui VI, Burr C, Leger R, Parmar J, Switzer T, Maedler S, Reiner EJ, Sherry JP, Simmons DBD (2015) Lithium an emerging contaminant: bioavailability, effects on protein expression, and homeostasis disruption in shortterm exposure of rainbow trout. Aquat Toxicol 161:85-93. doi:10.1016/j.aquatox.2015.01.030

11. Harari F, Åkesson A, Casimiro E, Lu Y, Vahter M (2016) Exposure to lithium through drinking water and calcium homeostasis during pregnancy: a longitudinal study. Environ Res 147:1-7. doi:10.1016 /j.envres.2016.01.031

12. Prigol M, Luchese C, Nogueira CW (2009) Antioxidant effect of diphenyl diselenide on oxidative stress caused by acute physical exercise in skeletal muscle and lungs of mice. Cell Biochem Funct 27:216-222. doi:10.1002/cbf.1559

13. Mossa ATH, Heikal TM, Mohafrash SMM (2014) Lipid peroxidation and oxidative stress in rat erythrocytes induced by aspirin and diazinon: the protective role of selenium. Asian Pac J Trop Biomed 4(Suppl 2):S603-S609. doi:10.12980/APJTB.4.2014APJTB2013-0038

14. El-Boshy ME, Risha EF, Abdelhamid FM, Mubarak MS, Hadda TB (2015) Protective effects of selenium against cadmium induced hematological disturbances, immunosuppressive, oxidative stress and hepatorenal damage in rats. J Trace Elem Med Biol 29:104110. doi:10.1016/j.jtemb.2014.05.009

15. Masaki C, Sharpley AL, Godlewska BR, Berrington A, Hashimoto T, Singh N, Vasudevan SR, Emir UE, Churchill GC, Cowen PJ (2016) Effects of the potential lithium-mimetic, ebselen, on brain neurochemistry: a magnetic resonance spectroscopy study at 7 tesla. Psychopharmacology 233:1097-1104. doi:10.1007/s00213015-4189-2

16. Abuelo A, Alves-Nores V, Hernandez J, Muiño R, Benedito JL, Castillo C (2016) Effect of parenteral antioxidant supplementation during the dry period on postpartum glucose tolerance in dairy cows. J Vet Intern Med 30:892-898. doi:10.1111/jvim.13922

17. Chelkeba L, Ahmadi A, Abdollahi M, Najafi A, Ghadimi MH, Mosaed R, Mojtahedzadeh M (2015) The effect of parenteral selenium on outcomes of mechanically ventilated patients following sepsis: a prospective randomized clinical trial. Ann Intensive Care 5:29. doi:10.1186/s13613-015-0071-y

18. Bosche B, Schäfer M, Graf R, Härtel FV, Schäfer U, Noll T (2013) Lithium prevents early cytosolic calcium increase and secondary injurious calcium overload in glycolytically inhibited endothelial cells. Biochem Biophys Res Commun 434:268-272. doi:10.1016 /j.bbrc.2013.03.047

19. Kiełczykowska M, Musik I, Pasternak K (2008) Relationships between silicon content and glutathione peroxidase activity in tissues of rats receiving lithium in drinking water. Biometals 21:53-59. doi:10.1007/s10534-007-9092-9

20. Dudev T, Lim C (2011) Competition between $\mathrm{Li}^{+}$and $\mathrm{Mg}^{2+}$ in metalloproteins. Implications for lithium therapy. J Am Chem Soc 133:9506-9515. doi:10.1021/ja201985s

21. Aksakal N, Erçetin C, Özçınar B, Aral F, Erbie Y (2015) Lithiumassociated primary hyperparathyroidism complicated by nephrogenic diabetes insipidus. Ulus Cerrahi Derg 31:166-169. doi:10.5152/UCD.2014.2859

22. Wielkoszyński T (2000) Modified, spectrophotometric method of silicon determination in biological material. Diagn Lab 36:377-385 (In Polish) 
23. Kiełczykowska M, Kocot J, Kurzepa J, Lewandowska A, Żelazowska R, Musik I (2014) Could selenium administration alleviate the disturbances of blood parameters caused by lithium administration in rats? Biol Trace Elem Res 158:359-364. doi:10.1007/s12011-014-9952-4

24. Harrison PJ, Cipriani A, Harmer CJ, Nobre AC, Saunders K, Goodwin GM, Geddes JR (2016) Innovative approaches to bipolar disorder and its treatment. Ann N Y Acad Sci 1366:76-89. doi:10.1111/nyas.13048

25. van Melick EJ, Wilting I, Ziere G, Kok RM, Egberts TC (2014) The influence of lithium on calcium homeostasis in older patients in daily clinical practice. Int J Geriatr Psychiatry 29:594-601. doi:10.1002/gps.4041

26. Baltaci AK, Sunar F, Mogulkoc R, Acar M, Toy H (2014) The effect of zinc deficiency and zinc supplementation on element levels in the bone tissue of ovariectomized rats: histopathologic changes. Arch Physiol Biochem 120:80-85. doi:10.3109 /13813455.2014.884141

27. de Eduardo CP, Simões A, de Freitas PM, Arana-Chavez VE, Nicolau J, Gentil V (2013) Dentin decalcification during lithium treatment: case report. Spec Care Dentist 33:91-95. doi:10.1111/scd.12000

28. Ghasemi A, Saberi M, Ghasemi M, Shafaroodi H, Moezi L, Bahremand A, Montaser-Kouhsari L, Ziai P, Dehpour AR (2010) Administration of lithium and magnesium chloride inhibited tolerance to the anticonvulsant effect of morphine on pentylenetetrazole-induced seizures in mice. Epilepsy Behav 19: 568-574. doi:10.1016/j.yebeh.2010.09.004

29. Sivrikaya A, Akil M, Bicer M, Kilic M, Baltaci AK, Mogulkoc R (2013) The effect of selenium supplementation on elements distribution in liver of rats subject to strenuous swimming. Bratisl Lek Listy 114:12-14. doi:10.4149/BLL 2013003

30. Kiełczykowska M, Musik I, Hordyjewska A, Boguszewska A, Lewandowska A, Pasternak K (2007) Oral administration of lithium increases tissue magnesium contents but not plasma magnesium level in rats. Pharmacol Rep 59:291-295

31. Csutora P, Karsai A, Nagy T, Vas B, Kovács GL, Rideg O, Bogner P, Miseta A (2006) Lithium induces phosphoglucomutase activity in various tissues of rats and in bipolar patients. Int J Neuropsychopharmacol 9:613-619. doi:10.1017/S146114570500622X

32. Markiewicz-Górka I, Zawadzki M, Januszewska L, HombekUrban K, Pawlas K (2011) Influence of selenium and/or magnesium on alleviation alcohol induced oxidative stress in rats, normalization function of liver and changes in serum lipid parameters. Hum Exp Toxicol 30:1811-1827. doi:10.1177 /0960327111401049

33. Nangliya V, Sharma A, Yadav D, Sunder S, Nijhawan S, Mishra S (2015) Study of trace elements in liver cirrhosis patients and their role in prognosis of disease. Biol Trace Elem Res 165:35-40. doi:10.1007/s12011-015-0237-3

34. Özkaya MO, Nazıroğlu M, Barak C, Berkkanoglu M (2011) Effects of multivitamin/mineral supplementation on trace element levels in serum and follicular fluid of women undergoing in vitro fertilization (IVF). Biol Trace Elem Res 139:1-9. doi:10.1007/s12011-0108637-x

35. Crujeiras V, Aldámiz-Echevarría L, Dalmau J, Vitoria I, Andrade F, Roca I, Leis R, Fernandez-Marmiesse A, Couce ML (2015) Vitamin and mineral status in patients with hyperphenylalaninemia. Mol Genet Metab 115:145-150. doi:10.1016/j.ymgme.2015.06.010

36. Holben DH, Smith AM, Ilich JZ, Landoll JD, Holcomb JP, Matkovic V (2002) Selenium intakes, absorption, retention, and status in adolescent girls. J Am Diet Assoc 102:1082-1087

37. Santos-López JA, Garcimartín A, Merino P, López-Oliva ME, Bastida S, Benedí J, Sánchez-Muniz FJ (2016) Effects of silicon vs. hydroxytyrosol-enriched restructured pork on liver oxidation status of aged rats fed high-saturated/high-cholesterol diets. PLoS One 11: e0147469. doi:10.1371/journal.pone.0147469 eCollection 2016

38. Zhao XQ, Mitani N, Yamaji N, Shen RF, Ma JF (2010) Involvement of silicon influx transporter OsNIP2;1 in selenite uptake in rice. Plant Physiol 153:1871-1877. doi:10.1104 /pp.110.157867

39. Malhotra A, Dhawan DK (2008) Zinc improves antioxidative enzymes in red blood cells and hematology in lithium-treated rats. Nutr Res 28:43-50. doi:10.1016/j.nutres.2007.11.002

40. Chadha VD, Bhalla P, Dhawan DK (2008) Zinc modulates lithiuminduced hepatotoxicity in rats. Liver Int 28:558-565. doi:10.1111 /j.1478-3231.2008.01674.x

41. Oktem F, Ozguner F, Sulak O, Olgar S, Akturk O, Yilmaz HR, Altuntas I (2005) Lithium-induced renal toxicity in rats: protection by a novel antioxidant caffeic acid phenethyl ester. Mol Cell Biochem 277:109-115. doi:10.1007/s11010-005-5426-5

42. Vijaimohan K, Mallika J, Shyamala DC (2010) Chemoprotective effect of sobatum against lithium-induced oxidative damage in rats. J Young Pharm 2:68-73. doi:10.4103/0975-1483.62217 